\title{
Efficacy of Feedback on Running Gait Retraining in Patients With Patellofemoral Pain: A Critically Appraised Topic
}

\author{
Hyunjae Jeon, MS, ATC, and Abbey C. Thomas, PhD, ATC \\ University of North Carolina at Charlotte
}

\begin{abstract}
Clinical Question: Is it beneficial to utilize feedback motion retraining in improving gait biomechanics, pain, and self-reported function on patients with patellofemoral pain (PFP)? Clinical Bottom Line: There is sufficient evidence to support the use of feedback motion retraining to improve gait, pain, and function in PFP rehabilitation.
\end{abstract}

Keywords: motion retraining, kinematics, patient-reported function

\section{Introduction/Clinical Scenario}

Healthcare providers frequently encounter patients with patellofemoral pain (PFP), a nontraumatic and nonabnormal structural pathology which is localized in the retropatellar region. ${ }^{5} \mathrm{PFP}$ accounts for up to $17 \%$ of visits to general practice physicians for knee pain. ${ }^{6}$ In recreational athletes, the prevalence may be closer to $25 \%$, with individuals participating in running- and jumpingrelated activities most commonly affected..$^{5,7}$ Patients with PFP often experience limitations of daily and physical activities. ${ }^{8}$ Athletes with prolonged symptoms of PFP may experience decreased performance and early cessation of their athletic careers. ${ }^{8}$ Recent evidence suggests that PFP in young adults is a precursor to subsequent patellofemoral osteoarthritis. ${ }^{9}$

A systematic review established numerous risk factors of PFP, including dysfunction of knee extensor and/or hip abductor musculature, increased Q-angle, abnormal vastii reflex timing, patellar compression or tilting, and increased ground reaction forces during landing. ${ }^{10}$ In combination with these risk factors, dynamic knee valgus during various movements may increase patellofemoral pressure and result in development of PFP. $5,11,12$ To correct dynamic valgus, researchers incorporated hip abductor musculature strengthening exercises, such as side lying hip abduction, clamshell, and resistive band exercises, into treatments. ${ }^{12}$ Most of these investigations resulted in pain alleviation and improved selfreported function, but biomechanics were not improved. ${ }^{13}$

Jeon and Thomas are with the University of North Carolina at Charlotte, Charlotte, NC. Address author correspondence to Hyunjae Jeon at hjeon2@uncc.edu.
Due to the ineffectiveness of the hip strengthening exercise in altering biomechanics, researchers and clinicians have begun incorporating feedback of biomechanical movement patterns into PFP rehabilitation. ${ }^{14}$ This feedback is often either verbal or visual. Notably, a single, verbal feedback session has demonstrated immediate reductions in vertical ground reaction force during landing..$^{15}$ Visual feedback is often provided via mirrors or videotape and has demonstrated improvements in dynamic valgus. ${ }^{16}$ Collectively, these studies suggest that using feedback during motion retraining is a beneficial addition to PFP rehabilitation treatment. This Critically Appraised Topic (CAT) serves to review the current evidence regarding the effectiveness of feedback motion retraining on pain, function, and running kinematics in patients with PFP. Running was selected because PFP is a common injury among runners. ${ }^{17}$ This will help healthcare providers to make evidence-based decisions regarding whether or not to use feedback gait retraining in treating PFP.

\section{Focused Clinical Question}

Is it beneficial to utilize feedback motion retraining in improving gait biomechanics, pain, and self-reported function on patients with PFP?

\section{Search Strategy}

A database search was conducted in July of 2017. The search terms used were:

- Patient/client group: patellofemoral pain

- Intervention: Feedback motion retraining, augmented feedback

- Outcome: kinematics, function

The sources searched included:

- CINAHL

- Medline

- PubMed

- Google Scholar 
Inclusion criteria were:

- Strength of Recommendation Taxonomy (SORT) Level 3 evidence or higher

- Studies that identify PFP criteria

- Studies that describe feedback motion retraining

Exclusion criteria were:

- Studies that did not perform motion analysis in lower extremities

- Studies using feedback motion retraining in combination with other treatments

- Articles published prior to 2010

- Pilot studies

\section{Evidence Quality Assessment}

Studies included were assessed with the Physiotherapy Evidence Database (PEDro) scale for randomized controlled trials (RCT) and the STrengthening the Reporting of OBservational studies in Epidemiology (STROBE) statement for non-RCT studies. All studies were evaluated using SORT. All assessments were performed by a single author $(\mathrm{HJ})$.

\section{Results of Search}

\section{Summary of Search, Evidence Appraised, and Key Findings}

The literature search was conducted to find studies that investigated the effectiveness of feedback running gait retraining on biomechanical, pain, and self-reported function in patients with PFP. All four studies used 2-week feedback gait retraining in movement pattern modification in patients with PFP that also displayed faulty movement patterns. The initial search process resulted in 21 possible studies for inclusion and total of four relevant articles met the inclusion criteria (Figure 1, Table 1).

All four studies used 2-week feedback gait retraining in movement pattern modification in patients with PFP. One study ${ }^{3}$ used a computer-programmed visual feedback and three studies used a combination of mirror, script, and verbal feedback (Table 2). ${ }^{1,2,4}$ All studies ${ }^{1-4}$ analyzed lower extremity kinematics and reported pain during running, and three studies additionally reported changes of self-reported function. ${ }^{1-3}$ A 1-month follow-up was performed

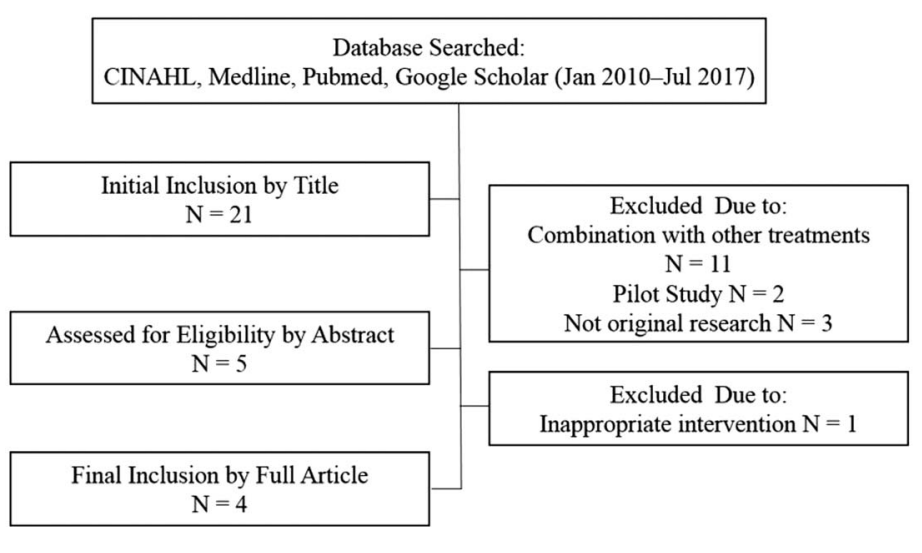

Figure 1 - Flow diagram to illustrate the search results. in all included studies and an extra 3-month follow-up was reported in two studies. ${ }^{1,2}$ Hip adduction angle and contralateral pelvic drop was significantly reduced in three studies ${ }^{1,3}$ and knee abduction angle $^{4}$ was improved immediately after the conclusion of the 2week feedback training. Pain reduction retained at 1 and 3 months and kinematic improvement was also reported in three studies. ${ }^{1,3,4}$

\section{Results of Evidence Quality Assessment}

Only one study ${ }^{4}$ utilized random allocation, using a random numbers generator which distributed participants into experimental and control groups. However, neither participants nor the investigator performing the intervention were blinded. Two studies ${ }^{1,3}$ were pretest/posttest studies that did not include a control group. One study ${ }^{2}$ was a case report of two participants from previous research. ${ }^{1}$ Our search process did not solely focus on RCTs since there was a lack of literature with a RCT design. For those reasons, studies received a PEDro score of 8/10; STROBE scores of 15/20, 17/20, and 10/20; and SORT ranging from 1 to 3 (Table 1).

\section{Clinical Bottom Line}

There is sufficient evidence to support the use of feedback motion retraining to improve gait, pain, and function in PFP rehabilitation. Three included studies ${ }^{1-3}$ found a significant reduction in hip adduction angle $(p<.05),{ }^{1,3}$ contralateral pelvic drop $(p=.001),{ }^{1,2}$ internal hip abduction moment $(p=.008),{ }^{1}$ and vertical loading impact $(p<.05)^{3}$ after intervention. Additionally, knee abduction angle and ankle plantar flexion improved after the gait retraining. ${ }^{1,4}$ Lastly, significant pain reduction ${ }^{1-4}$ and improvement of selfreported function ${ }^{1-3}$ was observed throughout the included studies, with Willy et al. observing very large effect sizes (pain: $d=7.61$, $p<.05$; function: $d=3.81, p<.05) .{ }^{1}$

SORT appraisal for the included articles resulted in scores ranging from level 1 to 3 (Table 1). The level 1 evidence $^{4}$ to support the use of feedback motion retraining was chosen because of its consistency and good quality patient-oriented evidence. The level 2 evidence was selected because one of the studies ${ }^{1}$ used an identical feedback method to the level 3 study and the other study used a unique mode of visual feedback. ${ }^{3}$ The level 3 evidence ${ }^{2}$ was included since it featured expanded outcome measures that were not included in the identical level 2 study. ${ }^{1}$ A single RCT ${ }^{4}$ was included and scored 8/10 on the PEDro scale with the only points lost being due to lack of blinding. According to the STROBE assessment, two articles ${ }^{1,3}$ were rated as high quality $(\geq 14 / 20)$ and one ${ }^{2}$ was rated as having a high risk of bias $(\leq 13 / 20)$. Collectively, the included evidence received a grade of B since the findings were consistent among included studies despite utilization of weak research designs. These studies suggest that providing feedback of movement patterns during gait retraining to patients with PFP is necessary to improve gait kinematics, pain, and self-reported function.

\section{Implications for Practice, Education, and Future Research}

PFP is a chronic condition resulting in retropatellar knee pain often exacerbated by faulty biomechanics, including increased hip adduction. ${ }^{18}$ The included studies identified consistent improvements in these aberrant gait kinematics after eight sessions (1530 min each) of feedback gait retraining. Providing programmed 
visual $^{3}$ and combination of mirror, script, and supplemental verbal feedback ${ }^{1,2,4}$ during motion retraining not only improved biomechanics but also improved pain and self-reported function in all included studies. Therefore, incorporation of the aforementioned modes of feedback to decrease hip adduction, internal rotation, knee valgus, and contralateral pelvic drop and increase ankle plantar flexion and range of motion appears beneficial to patients with PFP, especially those who displayed faulty movement patterns.

The feedback protocols examined were similar among included studies (Table 2). Specifically, all included research used eight training sessions during a 2 -week period and reduced the amount of feedback during the last four sessions. Also, all included studies targeted PFP patients who displayed faulty movement patterns. Noehren et al. ${ }^{3}$ utilized real-time visual feedback of participants' hip adduction angles during stance phase as a graph generated from 3D motion capture software. Participants observed their hip adduction angles during running and were instructed to keep the angle within one standard deviation of mean hip adduction angles obtained from healthy individuals. Participants were also instructed to contract their gluteal muscles and run with their knees pointing straight ahead; however, no additional verbal cues were provided when participants demonstrated any biomechanical errors during running. ${ }^{3}$ Willy et al. ${ }^{1}$ combined visual and verbal feedback during gait retraining. Participants were first shown video of their baseline movement so they could see their aberrant biomechanics. For the feedback portion, participants ran with a mirror in front of them so they could see their biomechanics in real time. They were provided the same instructions as in the Noehren et al. ${ }^{3}$ study prior to the start of each feedback session, which was to keep their knees apart and patella facing forward. Additional verbal feedback was provided once the faulty biomechanics were noticed. Roper et al. ${ }^{4}$ used the same mirror feedback as Willy et al., ${ }^{1}$ but provided different verbal instructions to encourage participants to run with a forefoot striking pattern since the purpose of the study was to alter the rearfoot strike pattern. Similar to Willy et al., ${ }^{1}$ verbal feedback was given if movement error was detected. Feedback methods of included studies altered faulty kinematics which were risk factors

\section{Table 1 Characteristics of Included Studies}

\begin{tabular}{|c|c|c|c|c|}
\hline & Noehren et al. ${ }^{3}$ & Willy et al. ${ }^{1}$ & Willy et al. ${ }^{2}$ & Roper et al. ${ }^{4}$ \\
\hline Study title & $\begin{array}{l}\text { The Effect of Real-Time Gait } \\
\text { Retraining on Hip Kinematics, } \\
\text { Pain and Function in Subjects } \\
\text { with Patellofemoral Pain } \\
\text { Syndrome }\end{array}$ & $\begin{array}{l}\text { Mirror Gait Retraining for the } \\
\text { Treatment of Patellofemoral } \\
\text { Pain in Female Runners }\end{array}$ & $\begin{array}{l}\text { Varied Response to Mirror } \\
\text { Gait Retraining of Gluteus } \\
\text { Medius Control, Hip Kine- } \\
\text { matics, Pain, and Function } \\
\text { in } 2 \text { Female Runners with } \\
\text { Patellofemoral Pain }\end{array}$ & $\begin{array}{l}\text { The Effects of Gait } \\
\text { Retraining in Runners } \\
\text { with Patellofemoral Pain: } \\
\text { A Randomized Trial }\end{array}$ \\
\hline $\begin{array}{l}\text { Study } \\
\text { participants }\end{array}$ & $\begin{array}{l}10 \text { female subjects with } \\
\text { patellofemoral pain } \\
\text { Average age: } 23.3 \text { years } \\
\text { Duration of pain: } 75.7 \text { months }\end{array}$ & $\begin{array}{l}10 \text { female runners with } \\
\text { patellofemoral pain } \\
\text { Average age: } 22.4 \text { years } \\
\text { Duration of pain: } 4.3 \text { years }\end{array}$ & $\begin{array}{l}2 \text { female runners with } \\
\text { patellofemoral pain } \\
\text { Age: } 20,23 \\
\text { Duration of pain: } 12 \text {, } \\
30 \text { months }\end{array}$ & $\begin{array}{l}16 \text { subjects }(11 \text { females, } \\
5 \text { males) were randomly } \\
\text { placed in the control }(n=8) \\
\text { or experimental group }(n=8) \\
\text { Average ages: control } \\
21.5 \text { years; experimental: } \\
24.6 \text { years }\end{array}$ \\
\hline $\begin{array}{l}\text { Inclusion/ } \\
\text { exclusion } \\
\text { criteria }\end{array}$ & $\begin{array}{l}\text { Inclusion criteria: patellofe- } \\
\text { moral pain; recreational } \\
\text { runners ( } 3 \text { times/week, total } \\
6 \text { miles/week or greater); } \\
\text { between ages of } 18 \text { and } 45 ; \\
\text { symptoms longer than } \\
2 \text { months; excessive hip } \\
\text { adduction, pelvic drop during } \\
\text { treadmill running } \\
\text { Exclusion criteria: cardiovas- } \\
\text { cular condition, injury which } \\
\text { can influence gait }\end{array}$ & $\begin{array}{l}\text { Inclusion criteria: patellofe- } \\
\text { moral pain; run at least } \\
10 \mathrm{~km} / \text { week; comfortable with } \\
\text { treadmill running at } 3.35 \mathrm{~m} / \mathrm{s} \text {; } \\
\text { free of any cardiac risk factors; } \\
\text { retropatellar or peripatellar } \\
\text { pain; visual analog scale } \geq 3 \\
\text { during running } \\
\text { Exclusion criteria: patellar } \\
\text { instability or other knee diag- } \\
\text { noses; history of any lower } \\
\text { extremity surgery; unhealthy }\end{array}$ & $\begin{array}{l}\text { Inclusion criteria: patellofe- } \\
\text { moral pain; run at least } \\
10 \mathrm{~km} / \mathrm{week} \text {; comfortable with } \\
\text { treadmill running at } 3.35 \mathrm{~m} / \mathrm{s} \text {; } \\
\text { free of any cardiac risk factors; } \\
\text { retropatellar or peripatellar } \\
\text { pain; visual analog scale } \geq 3 \\
\text { during running; excessive hip } \\
\text { adduction during running } \\
\text { Exclusion criteria: patellar } \\
\text { instability or other knee } \\
\text { diagnoses; history of any } \\
\text { lower extremity surgery; } \\
\text { unhealthy }\end{array}$ & $\begin{array}{l}\text { Inclusion criteria: patellofe- } \\
\text { moral pain during/after } \\
\text { running, squatting, kneeling, } \\
\text { stair ascent/descent, and pro- } \\
\text { longed sitting; visual analog } \\
\text { scale between } 3 \text { and 7; } \\
\text { self-reported rearfoot strike } \\
\text { runner } \\
\text { Exclusion criteria: pregnancy; } \\
\text { history of knee surgery on } \\
\text { the affected knee; traumatic } \\
\text { patellar dislocation; any } \\
\text { neurological impediments } \\
\text { that would influence gait }\end{array}$ \\
\hline $\begin{array}{l}\text { Outcome } \\
\text { measures }\end{array}$ & $\begin{array}{l}\text { Data points: Pre-post } \\
\text { treatment } \\
\text { Follow-up: } 1 \text { month } \\
\text { Hip adduction angle, hip } \\
\text { internal rotation angle, con- } \\
\text { tralateral pelvic drop angle, } \\
\text { visual analog scale, lower } \\
\text { extremity function index, } \\
\text { vertical impact load }\end{array}$ & $\begin{array}{l}\text { Data points: Pre-post } \\
\text { treatment } \\
\text { Follow-up: } 1,3 \text { month } \\
\text { Hip adduction angle, contra- } \\
\text { lateral pelvic drop angle, hip } \\
\text { internal rotation, internal hip } \\
\text { abduction moment, thigh } \\
\text { adduction, lower extremity } \\
\text { function scale, visual analog } \\
\text { scale } \\
\text { During: running, squatting, } \\
\text { stepping }\end{array}$ & $\begin{array}{l}\text { Data points: Pre-post } \\
\text { treatment } \\
\text { Follow-up: } 1,3 \text { month } \\
\text { Contralateral pelvic drop; hip } \\
\text { adduction angle; hip internal } \\
\text { rotation angle; gluteus medius } \\
\text { electromyographic activity; } \\
\text { during running, step ascend- } \\
\text { ing; pain (visual analog scale); } \\
\text { self-reported function (lower } \\
\text { extremity functional scale) }\end{array}$ & $\begin{array}{l}\text { Data points: Pre-post } \\
\text { treatment } \\
\text { Follow-up: } 1 \text { month } \\
\text { Knee pain during and after } \\
\text { running, knee abduction at } \\
\text { initial contact, knee flexion at } \\
\text { initial contact, range of motion } \\
\text { in the sagittal plane through } \\
\text { the loading response, ankle } \\
\text { plantar/dorsiflexion at initial } \\
\text { contact, peak patellofemoral } \\
\text { stress, Achilles tendon force, } \\
\text { patellofemoral contact force }\end{array}$ \\
\hline
\end{tabular}


Table 1 (continued)

\begin{tabular}{|c|c|c|c|c|}
\hline & Noehren et al. ${ }^{3}$ & Willy et al. ${ }^{1}$ & Willy et al. ${ }^{2}$ & Roper et al. ${ }^{4}$ \\
\hline Results & $\begin{array}{l}\text { Hip adduction significantly } \\
\text { decreased (pre }=22.0^{\circ} \pm 1.5, \\
\text { post }=16.5^{\circ} \pm 2.2, \text { mean } \\
\text { diff }=5.1, p<.01) . \text { Pelvic drop } \\
\text { decreased (pre }=-9.4^{\circ} \pm 2.5 \text {, } \\
\text { post }=-7.1^{\circ} \pm 1.6, \text { mean } \\
\text { diff }=-2.3, p<.05 \text { ) during } \\
\text { running. } \\
\text { Pain (pre }=5.0 \pm 2.0 \text {, } \\
\text { post }=0.5 \pm 1.3 \text { ) decreased } \\
\text { by } 86 \% \text { at the end of gait } \\
\text { retraining. } \\
\text { Lower extremity function } \\
\text { index improved by } 11 \text { points. } \\
\text { (pre }=64.0 \pm 11, \\
\text { post }=75.0 \pm 3.5 \text { ) } \\
\text { Impact loading variables } \\
\text { reduced with moderate to } \\
\text { large effect sizes ( } 0.45-1.10 \text { ). } \\
\text { Improvements in running } \\
\text { mechanics, pain, and function } \\
\text { retained at } 1 \text {-month follow-up. }\end{array}$ & $\begin{array}{l}\text { Running: significant }(p<.05) \\
\text { visible reduction in peak hip } \\
\text { adduction }(d=2.91) \text {, contra- } \\
\text { lateral pelvic drop }(d=0.82) \text {, } \\
\text { thigh adduction angle } \\
(d=1.32), \text { internal hip } \\
\text { abduction }(d=0.69) \text { moment, } \\
\text { hip internal rotation }(d=0.21) \text {. } \\
\text { Squat: hip adduction angle } \\
(d=1.35) \text {, thigh adduction } \\
\text { angle }(d=0.68), \text { internal hip } \\
\text { abduction moment }(d=0.91) \\
\text { were reduced }(p<.05) . \\
\text { Stepping: hip adduction } \\
\text { angle was reduced } \\
(d=0.69, p<.05) . \\
\text { Pain and lower extremity } \\
\text { function scale improved with } \\
\text { large effect sizes }(d=7.61, \\
d=3.81) . \\
\text { Retention was observed in hip } \\
\text { adduction angle and internal } \\
\text { hip abduction moment } \\
\text { improvement for } 3 \text { months } \\
\text { during running. }\end{array}$ & $\begin{array}{l}\text { During running, peak contra- } \\
\text { lateral pelvic drop (runner } 1: \\
2.6^{\circ} \text {, runner } 2: 1.7^{\circ} \text { ) and peak } \\
\text { hip adduction (runner } 1: 5.2^{\circ} \text {, } \\
\text { runner } 2: 6.3^{\circ} \text { ) were reduced } \\
\text { after intervention. } \\
\text { Earlier activation of the } \\
\text { gluteus medius relative to } \\
\text { foot strike (runner } 1: 12.6 \mathrm{~ms} \text {, } \\
\text { runner } 2: 37.3 \mathrm{~ms} \text { ) and longer } \\
\text { duration of gluteus medius } \\
\text { activity (runner } 1: 55.8 \mathrm{~ms} \text {, } \\
\text { runner } 2: 44.4 \text { ms) after } \\
\text { intervention. } \\
\text { Early onset of gluteus medius } \\
\text { activity during step ascent } \\
\text { (runner } 1: 48.0 \text { ms, runner } 2: \\
28.3 \text { ms). } \\
\text { Improvements in pain and } \\
\text { function maintained for } \\
3 \text { months. }\end{array}$ & $\begin{array}{l}\text { Significant knee abduction } \\
\text { angle improvement immedi- } \\
\text { ately postretraining }\left(\eta^{2}=0.29,\right. \\
p<.05) \text { and at } 1 \text {-month } \\
\text { follow-up }(p<.05) \text {. } \\
\text { Increased ankle plantar flexion } \\
\left(\eta^{2}=0.55\right) \text { and ankle range of } \\
\text { motion }\left(\eta^{2}=0.43\right) \text { immedi- } \\
\text { ately postretraining }(p<.05) \\
\text { and at } 1 \text {-month follow-up } \\
(p<.05) \text {. } \\
\text { Significant reduction in knee } \\
\text { pain immediately postretrain- } \\
\text { ing }\left(\eta^{2}=0.29, p<.05\right) \text { and at } \\
1 \text {-month follow-up }(p<.05) .\end{array}$ \\
\hline SORT & 2 & 2 & 3 & 1 \\
\hline $\begin{array}{l}\text { Quality } \\
\text { assessment }\end{array}$ & STROBE 15/20 & STROBE $17 / 20$ & STROBE 10/20 & PEDro 8/10 \\
\hline $\begin{array}{l}\text { Support for } \\
\text { the answer }\end{array}$ & Yes & Yes & Yes & Yes \\
\hline
\end{tabular}

Abbreviations: SORT = Strength of Recommendation Taxonomy; STROBE = STrengthening the Reporting of OBservational studies in Epidemiology.

for PFP and could have potentially contributed to the reduction of pain and improvement of function. ${ }^{19}$

Feedback of proper movement patterns is not unique to the PFP population. Biomechanical feedback to correct faulty movements is widely used to reduce the risk of sustaining other knee injuries, including anterior cruciate ligament (ACL) injuries. In fact, based on the success of feedback at improving jump-landing biomechanics, ${ }^{20-23}$ the use of feedback on proper movement technique is a key recommendation on the prevention of ACL injury. ${ }^{24}$ Further, feedback has been deemed beneficial in patients after ACL reconstruction to improve biomechanics. ${ }^{25}$ Collectively, these studies suggest the benefit of feedback to improve biomechanics across lower extremity injuries.

Both the immediate benefits and retention (1 and 3 months posttraining) of the treatment were studied. ${ }^{1-4}$ Noehren et al. ${ }^{3}$ reported reduced pain (mean difference $[\mathrm{MD}]=4.3, p=.001$ ) and improved self-reported function $(\mathrm{MD}=11.4, p=.008)$ immediately after the interventions. Immediate improvements in running mechanics were also observed across studies. Specifically, Willy et al. ${ }^{1}$ reported hip adduction angle improvement $(p<.001, d=$ $2.91)$ during running immediately after the intervention. One month after termination of the feedback interventions, patients continued to experience improvements. Hip adduction angle during running increased by $1.1^{\circ}$ at the 1-month follow-up; however, this change was associated with a small effect size $(d=0.37)$ since the magnitude of change was minimal compared to the initial improvement between baseline and immediate posttraining. ${ }^{1}$ Both Noehren et al. ${ }^{3}$ and Roper et al. ${ }^{4}$ reported that patients continued to experience reduced knee pain, knee abduction, and vertical loading with concurrent increased ankle range of motion at 1-month follow-up, with Roper et al. reporting a large effect size $\left(\eta^{2}=0.43\right)$. Finally, reductions in pain $(d=7.61)$ and improvements in lower extremity function $(d=3.81)$ were also reported 3 -months posttraining. ${ }^{1}$ Examining other interventions for patients with PFP suggests similar retention of improvements. Specifically, hip and knee strengthening exercises are widely adopted in the treatment of PFP and are effective in improving patient-reported outcomes through 1-year follow-up. ${ }^{26}$

Participants who underwent mirror gait retraining showed the greatest improvements with large effect sizes (pain: $d=7.61$, function: $d=3.81$ ) and residual effect for 3 months. ${ }^{1}$ Importantly, all participants included in these feedback studies presented with faulty movement patterns prior to gait retraining. Targeting individuals who present with faulty biomechanics appears critical to intervention success as these individuals have more room to improve their biomechanics than persons not presenting with excessive hip adduction. ${ }^{27}$

Future research should investigate the optimal treatment duration, dosage of feedback, and instructions provided. Instructions provided are important to consider given that the most recent and best quality evidence included presently demonstrated that instructing patients to modify their foot strike pattern improved both hip and knee biomechanics, which is of great importance to patients with PFP. ${ }^{4}$ Additionally, future studies should determine if including lower extremity strengthening exercises, which are popular during traditional rehabilitation, into these feedback interventions 


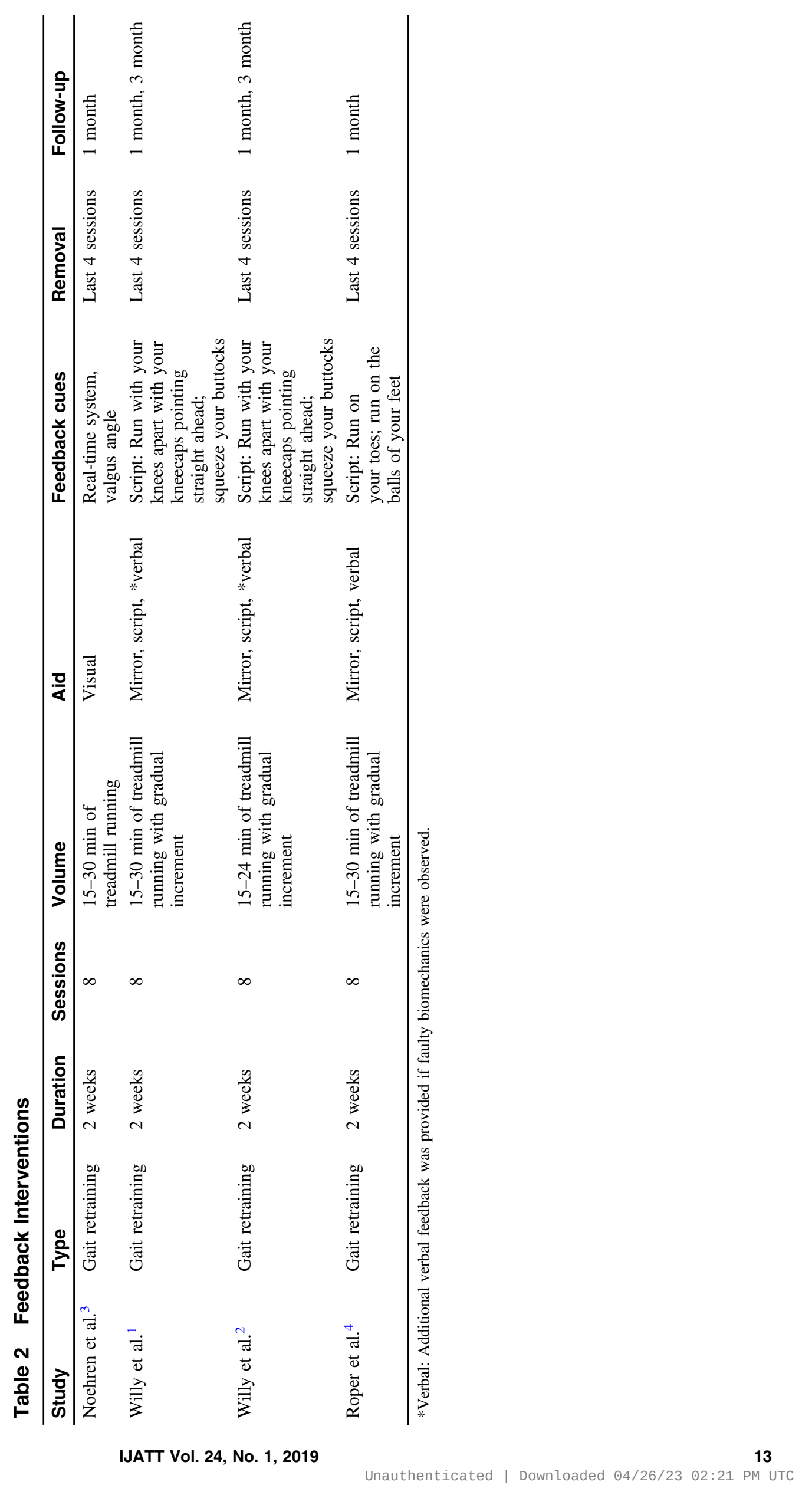


will yield a greater magnitude of training effect and longer residual benefits. Finally, research should include control groups to ensure the treatment effect is not simply due to time or random chance.

\section{CAT Kill Date: January 2021}

CATs have limited life and should be revisited approximately 2 years after publication (see https://doi.org/10.1123/ijatt.2018-0093).

\section{References}

1. Willy RW, Scholz JP, Davis IS. Mirror gait retraining for the treatment of patellofemoral pain in female runners. Clin Biomech (Bristol, Avon). 2012;27(10):1045-1051. PubMed ID: 22917625 doi:10.1016/j.clinbiomech.2012.07.011

2. Willy RW, Davis IS. Varied response to mirror gait retraining of gluteus medius control, hip kinematics, pain, and function in 2 female runners with patellofemoral pain. J Orthop Sports Phys Ther. 2013; 43(12):864-874. PubMed ID: 24175611 doi:10.2519/jospt.2013.4516

3. Noehren B, Scholz J, Davis I. The effect of real-time gait retraining on hip kinematics, pain and function in subjects with patellofemoral pain syndrome. Br J Sports Med. 2011;45(9):691-696. PubMed ID: 20584755 doi:10.1136/bjsm.2009.069112

4. Roper JL, Harding EM, Doerfler D, et al. The effects of gait retraining in runners with patellofemoral pain: a randomized trial. Clin Biomech (Bristol, Avon). 2016;35:14-22. doi:10.1016/j.clinbiomech.2016.03.010

5. Petersen W, Rembitzki I, Liebau C. Patellofemoral pain in athletes. Open Access J Sports Med. 2017;8:143-154. PubMed ID: 28652829 doi:10.2147/OAJSM.S133406

6. Crossley KM, Stefanik JJ, Selfe J, et al. 2016 Patellofemoral pain consensus statement from the 4th International Patellofemoral Pain Research Retreat, Manchester. Part 1: terminology, definitions, clinical examination, natural history, patellofemoral osteoarthritis and patient-reported outcome measures. Br J Sports Med. 2016;50(14): 839-843. PubMed ID: 27343241 doi:10.1136/bjsports-2016-096384

7. Barber Foss KD, Myer GD, Chen SS, Hewett TE. Expected prevalence from the differential diagnosis of anterior knee pain in adolescent female athletes during preparticipation screening. J Athl Train. 2012;47(5): 519-524. PubMed ID: 23068589 doi:10.4085/1062-6050-47.5.01

8. Glaviano NR, Baellow A, Saliba S. Physical activity levels in individuals with and without patellofemoral pain. Phys Ther Sport. 2017; 27:12-16. PubMed ID: 28780340 doi:10.1016/j.ptsp.2017.07.002

9. Thomas MJ, Wood L, Selfe J, Peat G. Anterior knee pain in younger adults as a precursor to subsequent patellofemoral osteoarthritis: a systematic review. BMC Musculoskelet Disord. 2010;11:201. PubMed ID: 20828401 doi:10.1186/1471-2474-11-201

10. Waryasz GR, McDermott AY. Patellofemoral pain syndrome (PFPS): a systematic review of anatomy and potential risk factors. Dyn Med. 2008;7:9. PubMed ID: 18582383 doi:10.1186/1476-5918-7-9

11. Dierks TA, Manal KT, Hamill J, Davis IS. Proximal and distal influences on hip and knee kinematics in runners with patellofemoral pain during a prolonged run. J Orthop Sports Phys Ther. 2008;38(8): 448-456. PubMed ID: 18678957 doi:10.2519/jospt.2008.2490

12. Ferber R, Kendall KD, Farr L. Changes in knee biomechanics after a hip-abductor strengthening protocol for runners with patellofemoral pain syndrome. J Athl Train. 2011;46(2):142-149. PubMed ID: 21391799 doi:10.4085/1062-6050-46.2.142

13. Thomson C, Krouwel O, Kuisma R, Hebron C. The outcome of hip exercise in patellofemoral pain: a systematic review. Man Ther. 2016;26:1-30. PubMed ID: 27428378 doi:10.1016/j.math.2016.06.003
14. Neal BS, Barton CJ, Gallie R, O'Halloran P, Morrissey D. Runners with patellofemoral pain have altered biomechanics which targeted interventions can modify: a systematic review and meta-analysis. Gait Posture. 2016;45:69-82. PubMed ID: 26979886 doi:10.1016/j. gaitpost.2015.11.018

15. Milner CE, Fairbrother JT, Srivatsan A, Zhang S. Simple verbal instruction improves knee biomechanics during landing in female athletes. Knee. 2012;19(4):399-403. PubMed ID: 21676618 doi:10. 1016/j.knee.2011.05.005

16. Munro A, Herrington L. The effect of videotape augmented feedback on drop jump landing strategy: implications for anterior cruciate ligament and patellofemoral joint injury prevention. Knee. 2014;21(5): 891-895. PubMed ID: 24950995 doi:10.1016/j.knee.2014.05.011

17. Taunton JE, Ryan MB, Clement DB, McKenzie DC, Lloyd-Smith DR, Zumbo BD. A retrospective case-control analysis of 2002 running injuries. Br J Sports Med. 2002;36(2):95-101. PubMed ID: 11916889 doi:10.1136/bjsm.36.2.95

18. Powers CM. The influence of abnormal hip mechanics on knee injury: a biomechanical perspective. J Orthop Sports Phys Ther. 2010; 40(2):42-51. PubMed ID: 20118526 doi:10.2519/jospt.2010.3337

19. Powers CM, Witvrouw E, Davis IS, Crossley KM. Evidence-based framework for a pathomechanical model of patellofemoral pain: 2017 patellofemoral pain consensus statement from the 4th International Patellofemoral Pain Research Retreat, Manchester, UK: part 3. Br J Sports Med. 2017;51(24):1713-1723. PubMed ID: 29109118 doi:10. 1136/bjsports-2017-098717

20. Ericksen HM, Thomas AC, Gribble PA, Doebel SC, Pietrosimone BG. Immediate effects of real-time feedback on jump-landing kinematics. J Orthop Sports Phys Ther. 2015;45(2):112-118. PubMed ID: 25552287 doi:10.2519/jospt.2015.4997

21. Mandelbaum BR, Silvers HJ, Watanabe DS, et al. Effectiveness of a neuromuscular and proprioceptive training program in preventing anterior cruciate ligament injuries in female athletes: 2-year followup. Am J Sports Med. 2005;33(7):1003-1010. PubMed ID: 15888716 doi: $10.1177 / 0363546504272261$

22. Etnoyer J, Cortes N, Ringleb SI, Van Lunen BL, Onate JA. Instruction and jump-landing kinematics in college-aged female athletes over time. J Athl Train. 2013;48(2):161-171. PubMed ID: 23672380 doi:10.4085/1062-6050-48.2.09

23. Hewett TE, Myer GD, Ford KR. Reducing knee and anterior cruciate ligament injuries among female athletes: a systematic review of neuromuscular training interventions. J Knee Surg. 2005;18(1):8288. PubMed ID: 15742602 doi:10.1055/s-0030-1248163

24. Padua DA, DiStefano LJ, Hewett TE, et al. National Athletic Trainers' Association position statement: prevention of anterior cruciate ligament injury. J Athl Train. 2018;53(1):5-19. PubMed ID: 29314903 doi:10.4085/1062-6050-99-16

25. Gokeler A, Benjaminse A, Welling W, Alferink M, Eppinga P, Otten B. The effects of attentional focus on jump performance and knee joint kinematics in patients after ACL reconstruction. Phys Ther Sport. 2015;16(2):114-120. PubMed ID: 25443228 doi:10.1016/j. ptsp.2014.06.002

26. Fukuda TY, Melo WP, Zaffalon BM, et al. Hip posterolateral musculature strengthening in sedentary women with patellofemoral pain syndrome: a randomized controlled clinical trial with 1-year follow-up. J Orthop Sports Phys Ther. 2012;42(10):823-830. PubMed ID: 22951491 doi:10.2519/jospt.2012.4184

27. Myer GD, Ford KR, Brent JL, Hewett TE. Differential neuromuscular training effects on ACL injury risk factors in "high-risk" versus "lowrisk" athletes. BMC Musculoskelet Disord. 2007;8:39. PubMed ID: 17488502 doi:10.1186/1471-2474-8-39 